\title{
資源の選定と調達から見た生産の仕組み 小規模住宅生産者による木造注文住宅の生産システムに関する研究 その 2 THE PRODUCTION MECHANISM FROM THE VIEWPOINT OF RESOURCE SELECTION AND ARRANGEMENT
}

Study on production system of wooden custom-built housing by small housing builders Part 2

角倉 英明 ${ }^{*}$ ，松村秀一**

Hideaki SUMIKURA and Shuichi MATSUMURA

\begin{abstract}
There are many small housing builders in Japan, a lot of which are generally principal contractors for wooden custom-built houses. They provide houses integrating various resources, but they don't own most of all. Therefore we are going to draw how they select and arrange resources through the results of the questionnaire survey and the hearing investigation. These researches were carried out with the purpose of gaining the production mechanism small housing builders share.

This study led that small housing builders have the followings tendency on resource selection and arrangement; 1) to select components with big initiative, 2) to purchase components on each construction work, 3) to use particular carpenters and subcontractors belonging to their business partnership, and 4) to acquire newly carpenter or subcontractor to improve lack of the quantity or quality.
\end{abstract}

Keywords : Small housing builder, Wooden custom-built house, Building resource, Integration, Construction 小規模住宅生産者，木造注文住宅，資源，統合，施工

\section{1. はじめに}

\section{1. 研究の背景と目的}

社会の成熟化による人口減少と価值観の多様化により、我が国の 新築住宅市場は今後、規模縮小と細分化が同時並行的に進行するこ とが想定される。この大きな構造変化によって住宅供給の担い手で ある事業者には、高い独自性と市場競争力を備えた生産活動が要求 される。特に、地域の最終的な生産主体であり ${ }^{1)}$ 、かつ木造注文住 宅の主要な生産主体でもある工務店等の小規模住宅生産者に及ぼす 影響は大きいものと考えられる。

このような現状認識の下、前稿注 1) において述べた通り、小規模 住宅生産者における独自性の高い木造注文住宅の生産システムのあ り様を解明することが本研究における最終的な目標である。

まず前稿では、小規模住宅生産者注 2) の事業形態を明らかにする ことを通じて、それらが多様な経験に基づき住宅に関わる知識・ノ ウハウを蓄積していることに加え、住宅生産に求められる資源を自 ら保有しておらず、その多くを外部から調達する傾向が強いことな じを示した ${ }^{2)}$ 。そこで、本稿では、木造注文住宅の元請業者として 生産活動を行う小規模住宅生産者が新築工事において資源を統合す るあり様を、職人並びに部品の選定と調達を対象に分析し、生産の 仕組みを明らかにすることを目的とする。

\section{2. 用語の定義}

\section{（1）資源統合}

住宅に限らず建築物を生産するには、その諸過程において、建築 物を構成する部品やこれを取り付ける職人、設計者等の多種多様な 資源が不可欠であり、それらを最適にまとめることによって的確な 品質を備えた建築物が供給される。そこで、本研究では、住宅生产 者が住宅を生産する過程において、そのもとになる資材・労働力な どを一つにまとめることを、「資源統合」と定義する。

\section{(2) 資源統合プロセス}

建築生産の現場では、個々に実態を備えた固有の資源が用いられ る。すなわち、個別の住宅が生産される過程においては、その都度 最適な部品や職人等の資源が選択・決定された上で、現場で適用で きるように準備・調整が図られ、最終的には適切な時期に用いられ る。そこで、本研究では、資源の「選定」、「調達」と「投入」とい う3つの要素行為が、住宅生産における資源統合プロセスを基本的 に構成すると定義する。

さらに、本研究では、「資源の選定」を木造注文住宅を新築する個 別の工事にどのような資源を用いるかを選択し、決定すること、並 びに、「資源の調達」を選定した資源を個別の新築工事に用いられる ように手配し、整えること、と定義する。
* 国土技術政策総合研究所 研究官・博士 (工学)

** 東京大学大学院工学系研究科建築学専攻 教授.工博 
表 1 アンケート調查の概要

\begin{tabular}{c|c}
\hline \multicolumn{2}{c}{ 木造注文住宅の生産システムに関するアンケート調査 } \\
\hline 調査内容 & 沿革、事業、組織形態、柂設、生産設備、職人、部品 \\
事業エリア、木造注文住宅の仕様、2005年度の業績など \\
\hline 調查方法 & 郵送による調查票の発送、回収 \\
\hline サンプル母集団 & 住宅性能保証制度登録業者（財団法人住宅保証機構） \\
\hline 調査期間 & 2007 年1月15日 2007年2月14日 \\
\hline 発送数・回収数 & 1484 社・205社 \\
\hline
\end{tabular}

表 2 ヒアリング調査対象

\begin{tabular}{|c|c|c|c|c|c|c|c|c|c|c|c|}
\hline $\begin{array}{l}\text { 事業 } \\
\text { 者名 }\end{array}$ & 所在地 & $\begin{array}{l}\text { 資本金 } \\
: \text { 万円 }\end{array}$ & $\begin{array}{c}\text { 創業 } \\
\text { 年 }\end{array}$ & $\begin{array}{l}\text { 従業 } \\
\text { 員数 }\end{array}$ & $\begin{array}{l}\text { 供給 } \\
\text { 戸数 }\end{array}$ & $\begin{array}{l}\text { 事業 } \\
\text { 者名 }\end{array}$ & 所在地 & $\begin{array}{l}\text { 資本金 } \\
\text { :万円 }\end{array}$ & $\begin{array}{l}\text { 創業 } \\
\text { 年 }\end{array}$ & $\begin{array}{l}\text { 従業 } \\
\text { 員数 }\end{array}$ & $\begin{array}{l}\text { 供給 } \\
\text { 户数 }\end{array}$ \\
\hline D1社 & 東京都 & 2000 & 文久 & 5 & 12 & T2社 & 海道 & 2001 & 1946 & 13 & 15 \\
\hline S1社 & 東京都 & 1000 & 1888 & 11 & 10 & S2社 & 道 & 2000 & 1958 & 22 & 28 \\
\hline N11社 & 千葉県 & 3000 & 1955 & 17 & 28 & 社 & 道 & 1000 & 1960 & & 7 \\
\hline A2社 & 千葉県 & 3000 & 1972 & 24 & 28 & 1社 & 道 & 5000 & 大正 & 20 & 20 \\
\hline K1社 & 埼玉県 & 3100 & 1966 & 20 & 25 & 511社 & 埼玉県 & 600 & 1945 & 3 & 4 \\
\hline S3社 & 東京都 & 1200 & 1952 & 8 & 12 & A1社 & 申奈川県 & 4500 & 1910 & 12 & 20 \\
\hline N2社 & 神奈川県 & 3000 & 1946 & 6 & 10 & M3社 & 東京都 & 4100 & 1950 & 25 & - \\
\hline W1社 & 東京都 & 3600 & 1948 & 18 & 28 & $\mathrm{O} 2$ 社 & 埼玉県 & 4000 & 1951 & 12 & 15 \\
\hline M1社 & 千葉県 & 1000 & 1959 & 8 & 13 & T5社 & 鹿児島県 & 1200 & 1973 & 10 & 12 \\
\hline K2社 & 東京都 & 1000 & 1955 & 5 & 5 & A3社 & 埼玉県 & 1000 & 1976 & 5 & 5 \\
\hline Y1社 & 岩手県 & 1600 & 1972 & 14 & 20 & T4社 & 宮城県 & - & $\begin{array}{ll}- \\
-\end{array}$ & 20 & - \\
\hline T3社 & 岩手県 & 2600 & 1954 & - & 3 & S4社 & 愛知県 & 4000 & 1959 & - & - \\
\hline K3社 & 岩手県 & 300 & 1973 & 3 & 6 & M2社 & 愛知県 & 1540 & 1949 & 6 & - \\
\hline 11社 & 岩手県 & 300 & 大正 & 12 & 2 & J1社 & 徳島県 & 5000 & 1974 & - & 10 \\
\hline
\end{tabular}

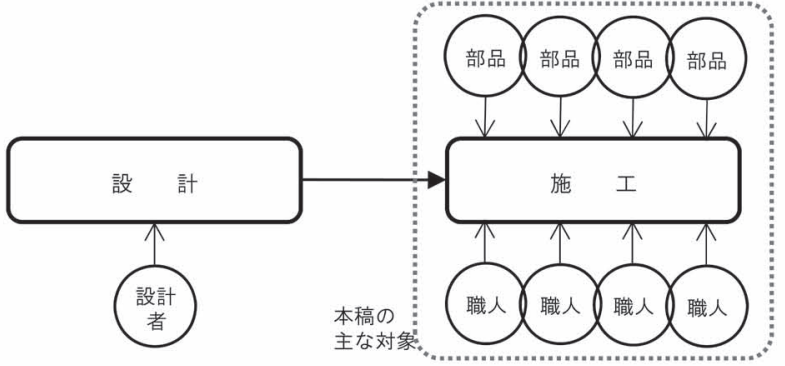

図 1 主要な生産段階から見た本研究の対象

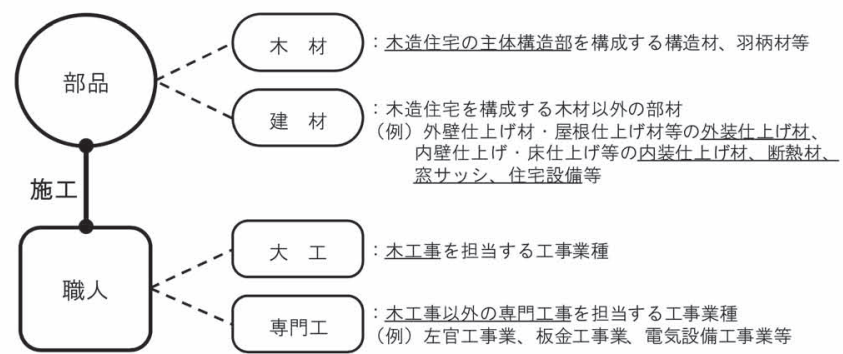

図 2 本研究において取り扱う主な資源
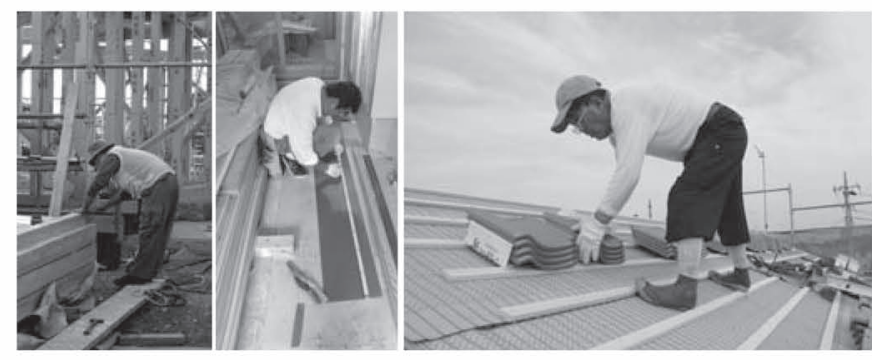

写真 1 部品一職人関係左）木材-大工、中）金属系外壁-板金工、右）瓦-屋根工

\section{3. 研究方法}

本稿では、前稿と同様に、2007 年に実施したアンケート調査（表 1）、及び小規模住宅生産者に対するヒアリング調查（表 2）の結果 をもとにする。具体的には、住宅保証機構の登録事業者に対するア ンケート調査の分析結果をインタビュー調査で得た結果及び知見等
によって補強することにより、資源統合のプロセスの実態を詳細に 明らかにする手法を採り、特にこれらの調查から得た結果の中から 資源統合・プロセスに関わる部分を中心的に整理した。

\section{4. 本稿における対象}

本研究で取り扱う小規模住宅生産者は、住宅保証機構による住宅 性能保証制度注3) の登録事業者を母集団とし、その特性は平均的な 年閒新築住宅供給棟数が 7.0 棟、従業員数が 8.0 名である ${ }^{2)}$ 。すなわ ち、ここでの主な分析対象は、木造注文住宅の元請業者として生産 活動を展開している小規模、かつ優良な住宅生産者と言える。

写真 1 や前記のように最終的に現場施工が欠かせないということ は建築生産における普遍的な特徵として明らかである。そこで、施 工段階において不可欠な資源となる、「部品」と「職人」を、本稿に おける主な対象とする。(図 1)

図 2 に示したように本研究では、部品を、木造住宅の主体構造部 分を構成する部材である「木材」と、その他の部位を構成する部材 である「建材」という2 つに大きく分類する。さらに建材は断熱材、 空サッシ、外装仕上げ材、内装仕上げ材及び住宅設備の 5 つに分け る。一方で、職人については、前稿と同様に、木工事を施す「大工」 とその他の専門工事を施す「専門工事業者」の 2 つに分類する ${ }^{3)}$ 。

木造住宅の新築工事では、通常、規則的な工程に従い、各種部品 に対応した工事業種の職人が工事を施す。そのため、部品及び職人 の投入は特定の時期に行われることが一般的であることは明らかで ある。したがって、資源統合プロセスを解明するため、本稿では、 選定注4) と調達に着目する。

\section{2. 部品から見た資源統合プロセス}

木造住宅において用いられる部品を木材と建材に分け、それらが 新築過程において選定、調達されるプロセスについて見る。

\section{1. 資源統合プロセスー木材 \\ （1）木材の選定}

図 3 によれば、小規模住宅生産者が木造注文住宅を供給する場合、 その新築工事において用いる木材は、個々の設計・施工の元請業者 （以下、工務店と略称する）が工事毎に選択・決定するケースと、 工務店が標準仕様により指定しているケースが共に $30 \%$ を超え、全 体の 7 割程度を占める。年間供給実績が大きくなると、標準仕様に よって指定する傾向が若干強くなる。木造注文住宅に用いる木材を、 工務店主導で選定することが一般的な手法となっている。

工務店主導による木材選定の要因として、第一に適材適所による 木材利用の必要性をあげられる。密度、各種強度、耐久性といった 性質は樹種によって異なる ${ }^{3)}$ 。部位により上手に使い分けることが 求められる木材選定には専門的知識や経験が不可欠となる。したが って、施主が主導的に選定すること自体が難しい。

前稿において明らかにしたように、小規模住宅生産者では組織代 表者自らが標淮仕様を設定することは一般的である注5)。仕様設定 には、木造住宅に用いる木材の適性に対寸る組織代表者の認識だけ でなく、T3 社や Y1 社等のように木材の地産地消の奨励等の木材利 用上の価值観や理念も働き、これらの条件に適合するものが選ばれ る。このような木材を自社の強み・長所として捉え、訴求効果を期 待する者もいる。すなわち、組織代表者の持つ木材とその仕様への こだわりも工務店主導の木材選定の要因としてあげられる。 


\begin{tabular}{|c|c|c|c|c|c|c|c|}
\hline & \multicolumn{7}{|c|}{ 木材の使い分け } \\
\hline & コスト & $\begin{array}{l}\text { 要求 } \\
\text { 性能 }\end{array}$ & $\begin{array}{l}\text { デザ } \\
\text { イン }\end{array}$ & 構工法 & 地域 & $\begin{array}{l}\text { 使い分 } \\
\text { けない }\end{array}$ & その他 \\
\hline 小規模住宅生産者（163） & $\underline{31.1}$ & $\underline{29.2}$ & 4.3 & 16.8 & 1.2 & 16.8 & 0.6 \\
\hline 3戸以下 (43) & $\underline{27.9}$ & $\underline{41.9}$ & 4.7 & 14.0 & 0.0 & 11.6 & 0.0 \\
\hline 10 戸以下 (76) & 35.5 & $\underline{25.0}$ & 2.6 & 17.1 & 1.3 & 18.4 & 0.0 \\
\hline 3 0戸以下 (44) & $\underline{26.2}$ & 23.8 & 7.1 & 19.0 & 2.4 & 19.0 & 2.4 \\
\hline
\end{tabular}

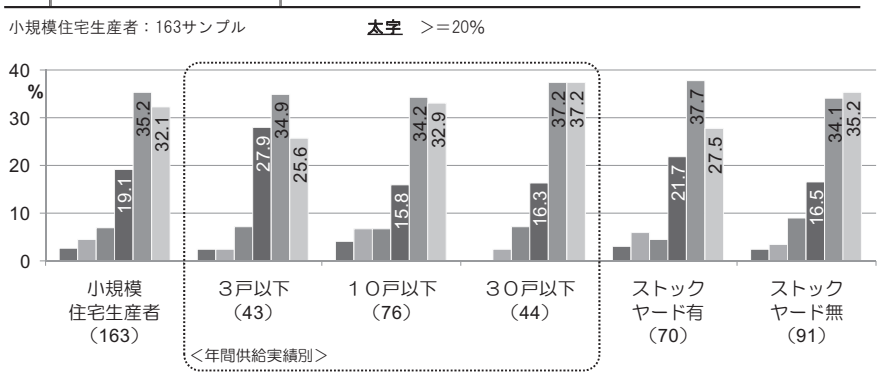

一施主自らが探して、選択・決定

自社で用意したカタログ等の資料から

" 自社メニューから施主が選択・決定自社メニュ

施主が選択・決定

自社メニューから工務店が選択・提案し

施主が決定

図 3 木材の選定方法

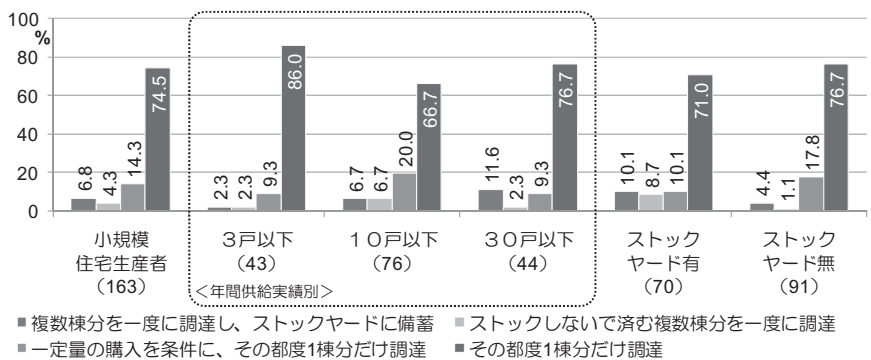

図 4 木材の調達方法

上記の傾向と共に、小規模住宅生産者では、木材を選定する上で、 主に木材の品質、価格及び性能などを重要視する特徴がある2)。こ れらの観点を含め組織代表者が高く評価する木材を、自社で設定す る標準仕様や自社メニュー等に反映していると理解できる。

また、前稿でも明記しているが、自社でストックヤードを保有す る工務店もある注 6)。そこに木材を大量に備蓄する場合には、機会 に応じて、それらを積極的に用いることが求められる。 $\mathrm{O} 1$ 社等のよ うに、木材の在庫処理を優先的に進める事例も確認できる。

さらに、木造住宅の建築工事費における木工事費の内訳は、建築 工事の 3 割程度、大工手間がその半分程度となるため、木材費は 10 〜 $15 \%$ 程度を占める ${ }^{4)}$ 。このような特徴を考慮して S 1 社などでは、 3 段階の木材仕様に応じて、3 種類の標準仕様を設定し、建築工事費 の目安となるような仕組みの構築を図っている。

つまり、ストックヤードでの木材備蓄や建築費用の調整効果の大 きさといったことも要因となっていると言える。

小規模住宅生産者においては、木造注文住宅の新築工事の規模・ 内容等に応じた適切な木材選定のため、必要に応じて工務店が樹種、 等級や材寸等を変更し、木材を使い分けることもある2)。

そこで、表 3 を見ると、要求性能やコストによって木材を使い分 ける工務店が多いことが分かる。このことは既述のように木材を適 材適所に用いる必要性や、施主の予算内での仕様の確定といった対 応の結果である。例えば、前記の $\mathrm{S} 1$ 社や $\mathrm{A} 2$ 社等では、坪単価によ

つて標準仕様を複数設定し、木材を使い分けている。また、N2 社の ように、金物構法採用の有無によって木材を使い分けている事例も ある。ただし、 $\mathrm{K} 3$ 社や $\mathrm{T} 3$ 社などのように、自社、特に組織代表者 のこだわりや条件を満たす木材の積極的活用により、自社の強みや 独自性、並びに他社との差別化の構築を図ることを目的に木材を使 い分けないケースもある注7)。

\section{（2）木材の調達}

図 4 が示寸ように、小規模住宅生産者は木造注文住宅において用 いる木材を通常、新築工事を請負う度に、その都度 1 棟に必要な量 だけ調達する。木材を都度購買する割合は年間供給規模別では若干 の差異が見られるが、おおよそ全体の 8 割弱であり、一定量購入の 条件付き都度購買を含めれば約 9 割に達する。

木造注文住宅の年間供給実績別に見ると、年間 3 戸以下では 8 割 以上の工務店が都度購買による木材調達を行っている。一方で、一 度に木材を複数棟分購入し、ストックヤードに備蓄している工務店 の占める割合は、規模が大きくなるに従って、増加する傾向を読み 取れる。ただし、年間 30 戸以下でも 1 割強であり、さらにストック ヤードを保有している工務店においても 1 割程度であるため、木材 を備蓄する傾向が弱いことが分かる

1980 年以降、全国でプレカット材が急速に普及した。現在、その 割合は 8 割を超え ${ }^{5)}$ 、構造材だけに限らず、羽柄材や造作材につい ても通常、プレカット工場において調達・加工されたものが使用さ れる。さらに、現場搬入や建て方の請負などの附帯機能の充実が図 られるようになっている。そのため、小規模住宅生産者が自社で木 材を調達し、加工する機会が減少している ${ }^{6)}$ 。

また、備蓄する木材の在庫処理を優先的に進めている 01 社に従 えば、新築住宅市場の縮小や多様化・個別化、木材価格の下落とい った市場環境の下では、一括購買よる木材の大量備蓄は、規模が小 さい住宅生産者にとって経営上のリスクになりや寸い。

さらに、前稿で明らかにしたように、ストックヤードの保有率は 決して高くない。すなわち、小規模住宅生産者が木材を備蓄するこ と自体が難しい状況にあると判断できる。

これらのことから、小規模住宅生産者が木材を都度購買する主な 要因は、プレカット材の普及、市場環境における不確実性の高まり、 並びにストックヤードの保有率の低さにあると言える。

\section{2. 資源統合プロセス一建材 \\ （1）建材の選定}

小規模住宅生産者が通常採っている、木造住宅の主体構造部以外 を構成する建材全般の選定方法について図 5 で見ると、自社で設定 したメニューの中から工務店が提案するケースが、部材の種類に関 わらず多く、その割合は 3 割前後である。一方で、施主自ら選択・ 決定したものを採用するケースは非常に少ない。

次いで建材種別に見ると、住宅設備と仕上げ材の選定については、 施主が選択・決定したものを採用寸る傾向が若干強いことを読み取 れる。ただし、工務店の用意するカタログや自社メニューの中から 施主が選択していることからすれば、工務店側によって事前に検 索・選抜されたものが、通常使用されていると判断できる。

つまり、小規模住宅生産者では、木造注文住宅に使用される建材 は全般的に木材と同様に、工務店主導で選定されることが一般的で あると言える。 
工務店主導による建材選定の主な要因としては、木材と同様に、 工務店の知識や経験等に起因するこだわりと共に、それに基づく標 準仕様や自社メニューの設定をあげられる。例えば D1 社では、組 織代表者が描く理想的な木造住宅像を具現化するため、適当な部材 を探索・選抜した上で、その性能や品質、コス卜等の様々な側面か ら比較検討し、最適なものを標準仕様へ取り込んでいる。また、S1 社のように組織代表者が設計業務の大部分を担い、平面計画や意匠 に限らず、予算に応じて詳細な仕様を決定している事例もある。

また、T1 社によれば、標準仕様等で指定した特定の部材を継続的 に使用することによって、施工精度のバラッキを抑制できる。その 結果、事前に仕上がりや工期等をある程度予測することが可能とな る。すなわち、不確実な要素の減少により、生産性の向上とリスク 管理の効果を得られることが分かる。

表 4 建材の使い分け

\begin{tabular}{|c|c|c|c|c|c|c|c|c|}
\hline & \multicolumn{7}{|c|}{ 建材の使い分け } \\
\hline & & コスト & $\begin{array}{l}\text { 要求 } \\
\text { 性能 }\end{array}$ & $\begin{array}{l}\text { デザ } \\
\text { イン }\end{array}$ & 構工法 & 地域 & $\begin{array}{c}\text { 使い分け } \\
\text { ない }\end{array}$ & その他 \\
\hline \multirow{5}{*}{$\begin{array}{l}\text { 建 } \\
\text { 材 } \\
\text { 種 } \\
\text { 別 }\end{array}$} & 断熱材 & $\underline{32.9}$ & $\underline{41.6}$ & 4.3 & 5.0 & 1.9 & 14.3 & 0.0 \\
\hline & 悹サッシ & $\underline{29.4}$ & $\underline{41.9}$ & 14.4 & 2.5 & 0.6 & 11.3 & 0.0 \\
\hline & 外装仕上げ材 & $\underline{28.4}$ & $\underline{23.5}$ & $\underline{33.3}$ & 3.7 & 0.6 & 10.5 & 0.0 \\
\hline & 内装仕上げ材 & $\underline{27.8}$ & $\underline{23.5}$ & $\underline{33.3}$ & 2.5 & 0.6 & 12.3 & 0.0 \\
\hline & 住宅設備 & $\underline{32.1}$ & $\underline{42.6}$ & 11.7 & 1.9 & 0.0 & 11.7 & 0.0 \\
\hline
\end{tabular}

小規模住宅生産者：163サンプル太字 $>=20 \%$

【年間供給实績別の傾向：30戸以下の比率一 3 戸以下の比率】白字 $15 \%$ 以上

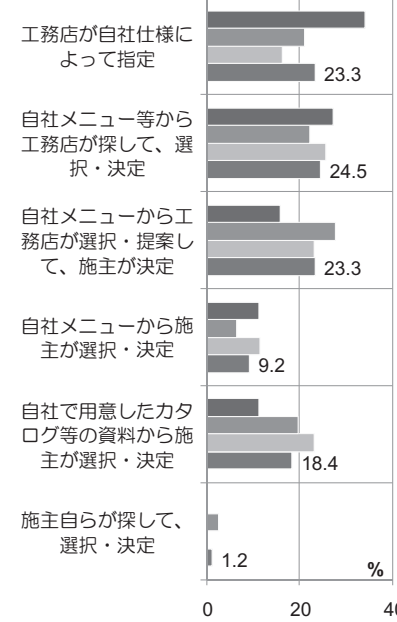

(1) 断熱材

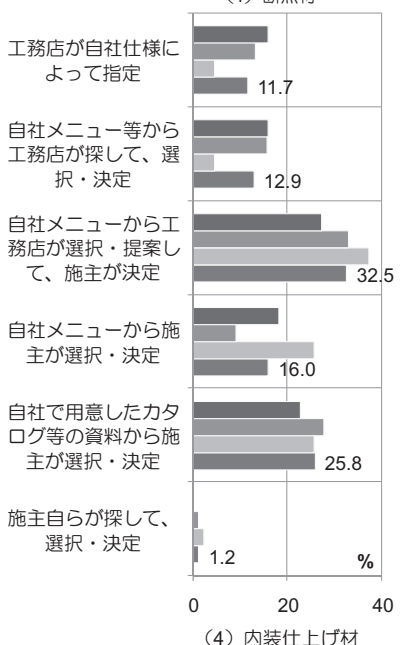

図 5 建材の選定方法

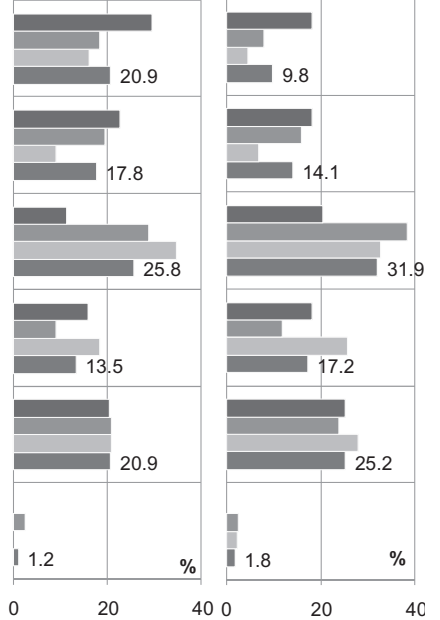

(3) 外装仕上げ材

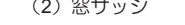

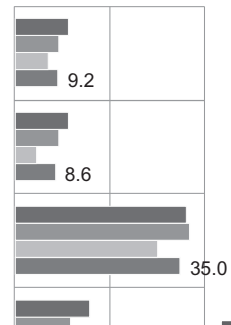

- 30戸以下 (44)

물 10戸以 (76)

- 3戸以下 (43)

小規模生産者住宅

生産者 (163)

※グラフ内のデー

夕は、小規模往宅 ての比率

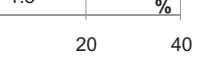

小規模住宅生産者では、共通的に品質、価格および性能を、建材 の条件として求める。部位別に見ると、住宅設備については、特に 性能を重要視し、デザインや知名度・ブランドを条件とする傾向も 若干強い。仕上げ材や空サッシ、断熱材については、施工のしやす さを条件とする工務店が若干多い4)。また表 4 を見ると、仕上げ材 についてはデザインによって使い分けられる傾向も強いが、全般的 には性能とコス卜によって使い分けられている。これらのとから、 小規模住宅生産者では通常、コストと性能を中心に建材を複合的に 評価し、固有の部材を具体的に選定していると言える。

\section{（2）建材の調達}

図6が示すように、小規模住宅生産者のうち 8 割程度の工務店は、 新築工事の都度 1 棟ずつ必要量の建材を調達している。さらに、メ 一カーや問屋、小売店等との条件付きで都度購買を採用する工務店 を合わせると、その割合は 95\%程度に達する。したがって、小規模 住宅生産者における建材調達は都度購買が一般的であると言える。

先述のように小規模住宅生産者ではストックヤードを保有してい る工務店は決して多くない。したがって、建材についても一括購買 し、備蓄する機能自体を備えていないことを要因として挙げられる。 また、特に仕上げ材や住宅設備などについては、デザインや付加 機能等といった点への施主の細かな要望が反映されやすい7)。つま り、木造注文住宅を主に供給する規模が小さい個々の工務店にとつ て、特定の部品を複数棟分に相当する量を一括購買することは大き なリスクとなり得る。すなわち、小規模住宅生産者には都度購買が 適していると言える。なお、これには色、模様、形状等が異なる同 一部品や類似部品等に代表される、部品メーカーによる多様なオー プン部品の製造と市場への供給も深く関連している。
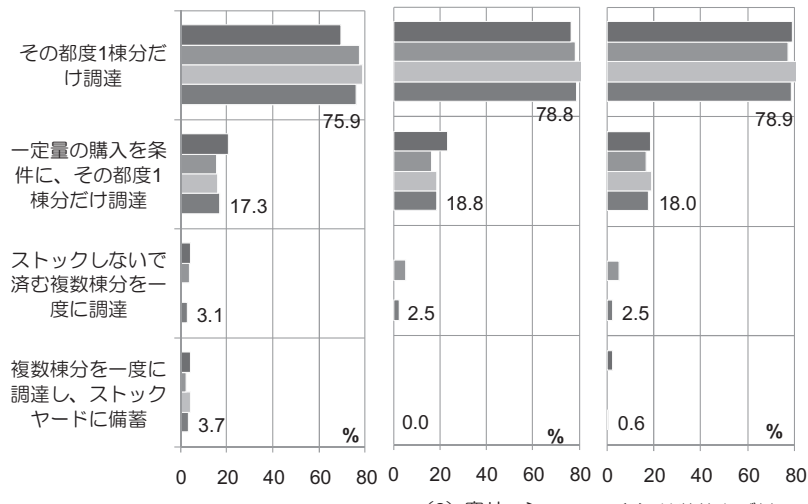

(1) 断熱材

(2) 空サッシ
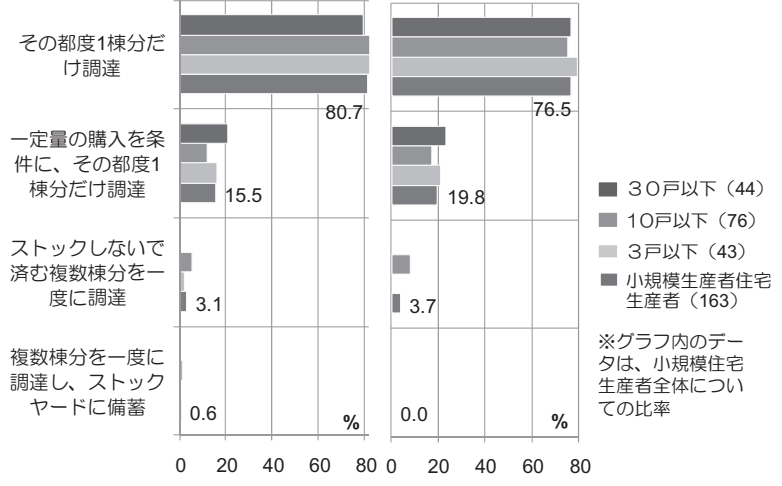

(4) 内装仕上げ材

（5）住宅設備

図 6 建材の調達方法 
表 5 大工の使い分け

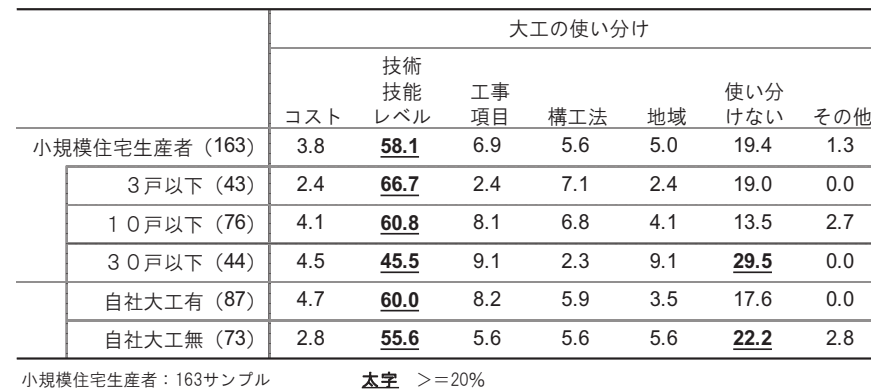

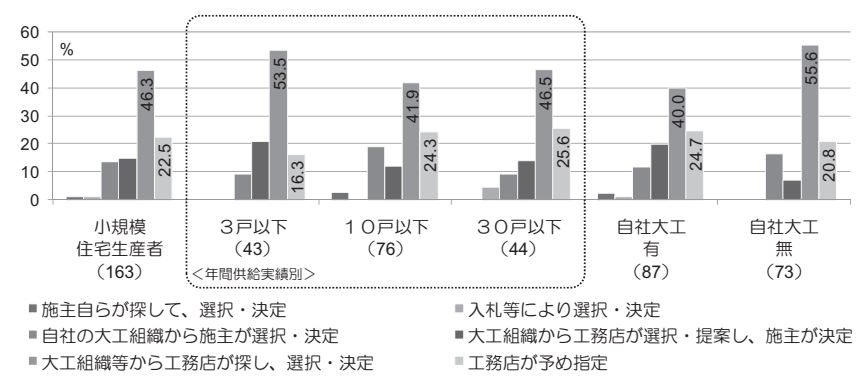

図 7 大工の選定方法

建材は通常、部品メーカーの工場にてロット単位で一定量が製造 される。この上、小規模住宅生産者による木造住宅の生産現場では、 工務店 1 社の必要とする量は少なく、特定の部品に関わる取引量の 多い専門工事業者が材料の手配を含めた材工共で工事を請負うこと が一般的である。すなわち、建材の製造や流通のあり方も、小規模 住宅生産者が都度購買する要因の 1 つとして挙げられる。

前述のように工務店単独では部品取引量が少ないために、小規模 住宅生産者ではその調達コストが課題となる。そこで、複数工務店 で形成されたグループによる部品の共同購買・流通の短絡化や、全 国各地で工務店を組織化する部品メーカー等によるフランチャイズ への加盟などにより、調達コストの低減を目的にした取り組みもあ る ${ }^{8)}$ 。ただし、松村が指摘するように、このような部品調達のあり 方は工務店同士で類似性の高い住宅を供給する可能性を高める ${ }^{6)}$ 。

\section{3.職人から見た資源統合プロセス}

本章では、木造住宅の建設現場で部品の取り付けを担う職人を大 工と専門工事業者に分け、それらが新築工事に投入されるプロセス を、選定と調達の 2 つの側面から捉える。

\section{1. 資源統合プロセス一大エ}

\section{（1）大工の選定}

木造住宅の新築工事に投入される大工は、図 7 が示すように、工 務店により工事毎に選択・決定されるケースと予め指定されている ケースが多い。それらを合わせると、全体の約 7 割に達する。一方、 施主による選択・決定は非常に少なく、その場合も工務店が自社で 形成する大工組織の中から選ばれることが実情である。すなわち、 小規模住宅生産者では、大工の選定は工務店主導で行われることが 一般的であり、施主の関与度合いは非常に低いと言える。

前稿で記述したように、小規模住宅生産者では、専属的に利用可 能な自社大工によって大工組織を形成する工務店は多(注8)。それ らを最大限に活用することが、事業の合理的な運営上で求められる。 すなわち、第 1 の要因は、大工の専属化である。
表 6 職人に求める重要な条件

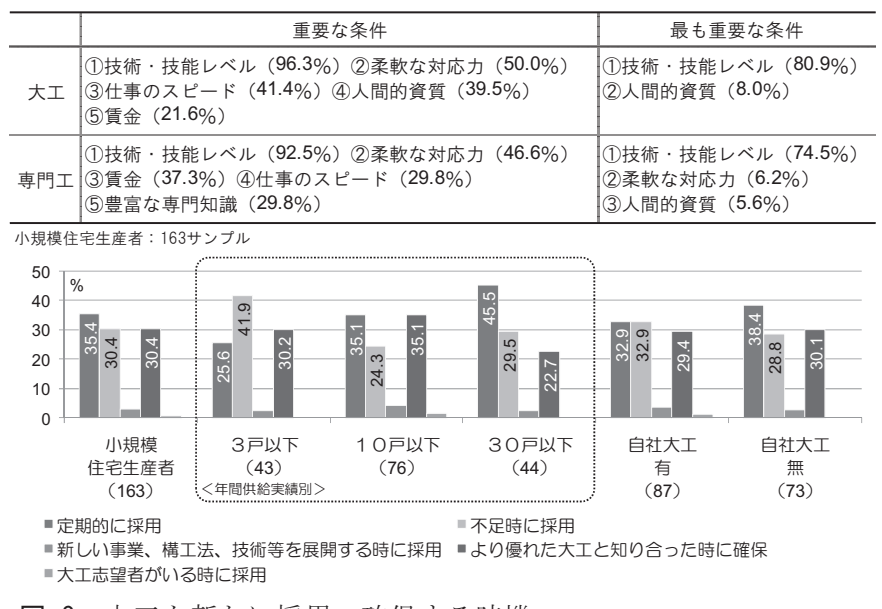

図 8 大工を新たに採用・確保する時機

第 2 の要因は、施工精度と品質の確保である。小規模住宅生産者 は技術・技能水準を十分に把握している大工を用いることにより、 施工精度及び仕上がりをある程度予測できる。そのため、M3 社、 $\mathrm{O} 1$ 社、 $\mathrm{T} 3$ 社などの多くの工務店では、手戻りの減少等により、合 理的な品質管理につながると考えている。

同じ木造軸組構法で建設された木造住宅であっても、工務店によ って仕様や納まり等の詳細部分は異なる。さらに、各種工事が複雑 に関連する工程の中、工期内に完成させるため、大工には仕事のス ピードが求められる。そのために $\mathrm{T} 3$ 社等では、精度の高い工事を 短期間に施すことを目的として、建設現場で工事を施す職人を限定 して用いている。つまり、工事の生産性も要因として挙げられる。

また、大工に限らず職人の条件として、技術・技能レベル以外に も人間的な資質を求める傾向が強い（表 6)。職人は建設現場で施主 と出会う機会が多く、彼等の作業態度は工務店と施主との信頼関係 や顧客満足に影響を及ぼす。そのため、小規模住宅生産者では人間 的な資質を十分に評価できる職人を自ら選択・決定する必要性が生 じる。つまり、施主との関係性の維持という要因も挙げられる。

なお、表 5 によれば、小規模住宅生産者は技術・技能レベルによ って大工を使い分ける傾向が強い。例えば、M3 社等では、木工事 の技術要件に差異が生じることを理由に、プレカット材採用の有無 によって大工を使い分けている。つまり、小規模住宅生産者は大工 の備える技術・技能を事前に把握し、個別の工事に求められる技術 技能水準を評価した上で、適切な大工を投入していることが分かる。

\section{（2）大工の調達}

小規模住宅生産者は通常、工事受注時に、外部の協力大工も含ん で予め形成する大工組織の中から固有の大工を選定・投入する。そ こで、ここでは新たな大工の採用・確保を大工の調達として捉える。

図 8 に従えば、小規模住宅生産者では定期的・不足時、並びに優 れた大工と面識を持った時に、新たな大工を採用・確保する工務店 が多い。それぞれ 3 割程度あり、これらが一般的な機会になってい ると言える。また年間供給実績別に着目寸ると、定期的な大工採用 は規模の大きい 30 戸以下、一方で不足時における大工採用は最も小 さい 3 戸以下において傾向が強いことを読み取れる。

小規模住宅生産者とは文字通り事業規模が小さな住宅生産者であ り、それを維持するために要する大工数は相対的に少ない。言い換 
えれば、大工組織の規模は小さくて済む。さらに、大工は通常、小 規模住宅生産者と長期的な取引関係を構築する。また、一時的な工 事受注の集中や増加による大工の不足に対しても、弾力的な取引関 係を構築しやすい協力大工を用いた調整とともに、施主と相談の上、 着工時期の遅延といった対応が図られることが一般的である。した がって、新たな大工を採用・確保する機会は少ないと言える。

これらの傾向に大工が高齢化傾向にある現状を加味すれば9)、大 工の定期的な採用とは、長い期間の中での大工組織の規模及び質の 最適化や高齢化一の対応であると考えられる。なお、他の工務店・ 大工等からの紹介、寸なわち縁故を通じた大工の採用が一般的であ るが、 $\mathrm{W} 1$ 社や $\mathrm{K} 1$ 社等のように長期的な視点から独立・退職による 大工の不足を想定し、独自の大工育成プログラムを設け、定期的に 非熟練の大工を採用するケースもある。

また、優れた大工との面識を持つことが新たな大工の採用・確保 につながっていることが読み取れる。これは小規模住宅生産者では、 技術・技能レベルや柔軟な対応力、人間的資質といった大工に求め る条件を備えた、即戦力として期待できる熟練大工の確保が図られ ていることを意味している。

寸なわち、小規模住宅生産者では、大工組織の量的な不足を補う ための新規採用とともに、その質的満足のための大工確保により、 自社の大工組織を維持していると言える。

なお、前述のようにプレカット材採用の有無により、木工事の技 術要件は異なる。それはプレカット材が工場で高精度に機械加工さ れた木材であり、その採用は大工による墨付けを含む手加工、伏図 作成や水平・垂直調整等の作業を省略・軽減するためである。しか し、今後改修工事の増加に伴い、現場ではそれらの能力が技術要件 となるケースも増加する。そこで、小規模住宅生産者の中にはプレ カット材を積極的に採用した上で、大工育成を目的に彼等が手加工 等の技能を習得できる機会創出を図るケースもある注 9)。

\section{2. 資源統合プロセス一専門工事業者}

\section{（1）専門工事業者の選定}

図 9 によれば、小規模住宅生産者では、工事毎に自社で専門工事 業者を選択・決定する者が最も多く、その割合は半数を超える。次 いで、自社で予め指定している者が多い。その割合は約 $1 / 4$ になる。 これらを合わせると 8 割弱になる。なお、年間供給実績による大き な差異も特に確認できない。したがって、小規模住宅生産者では通 常、工務店主導で専門工事業者を選定していると言える。

工務店主導による選定の主な要因は、 $\mathrm{A} 1$ 社、 $\mathrm{T} 3$ 社や $\mathrm{M} 2$ 社など によれば、大工と同様に、品質の確保、工事の生産性の向上であり、 また施主との信頼関係を安定して得るためでもある。

しかし、専門工事業者は社外組織であるという大工と異なる特徵 を持つ。そして、小規模住宅生産者は全般的に 1 業種 1 業者という かたちで特定の専門工事業者と取引関係を構築し、それらをメンバ 一とする協力業者会を形成している ${ }^{2)}$ 。このことは、専門工事業者 からすれば安定的な工事受注に結び付き、小規模住宅生産者にとっ ては各種専門工事の発注先を固定・集中させる効果がある。すなわ ち、各種専門工事を担当する専門工事業者を限定することが結果と して、木造住宅の品質、生産性、および顧客との信頼関係の安定的 な確保にもつながっていると判断できる注10)。

なお、専門工事業者の選定には、大工と同様に技術・技能水準と人
間的資質という条件に加え、柔軟な対応力や賃金が重要視されてい る（表 6)。また、技術・技能レベル以外に工事費によって使い分け られる傾向も比較的強い（表 7)。すわわち、柔軟な対応力も含む技 術的な要件を前提として、専門工事業者を選択可能な場面では費用 面を考慮に入れた判断に基づき、協力業者会内の適切なメンバーに 発注していることが分かる。

表 7 専門工事業者の使い分け

\begin{tabular}{|c|c|c|c|c|c|c|c|}
\hline & \multicolumn{7}{|c|}{ 専門工の使い分け } \\
\hline & コスト & $\begin{array}{c}\text { 技術 } \\
\text { 技能 } \\
\text { レベル }\end{array}$ & $\begin{array}{l}\text { 工事 } \\
\text { 項目 }\end{array}$ & 構工法 & 地域 & $\begin{array}{c}\text { 使い分け } \\
\text { ない }\end{array}$ & その他 \\
\hline 小規模住宅生産者 (163) & $\underline{22.2}$ & $\underline{40.1}$ & 7.4 & 6.8 & 8.0 & 14.8 & 0.6 \\
\hline 3戸以下 (43) & $\underline{20.9}$ & 37.2 & 9.3 & 4.7 & 7.0 & $\underline{20.9}$ & 0.0 \\
\hline 10 戸以下 (76) & $\underline{24.0}$ & 40.0 & 6.7 & 6.7 & 9.3 & 13.3 & 0.0 \\
\hline 30 戸戸以下 (44) & 20.5 & 43.2 & 6.8 & 9.1 & 6.8 & 11.4 & 2.3 \\
\hline
\end{tabular}

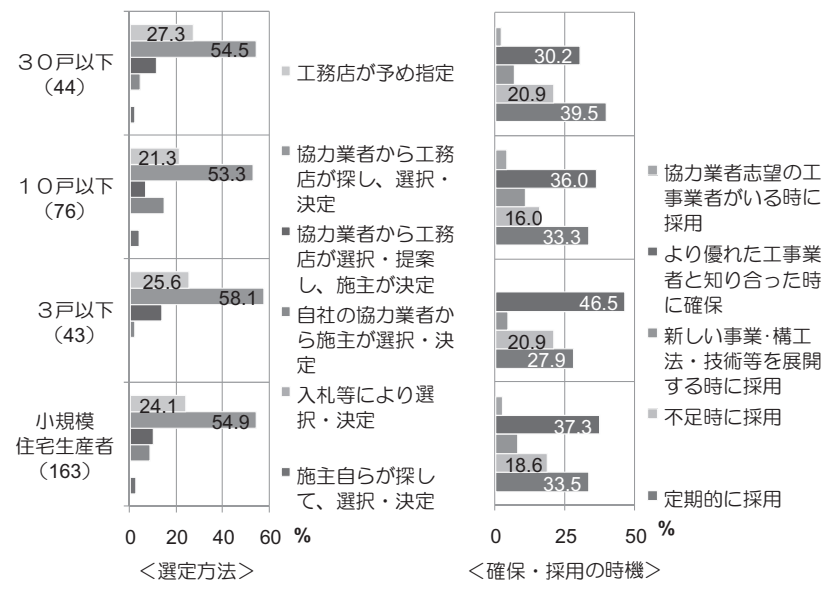

図 9 専門工事業者の選定方法（左）と採用・確保時機（右）
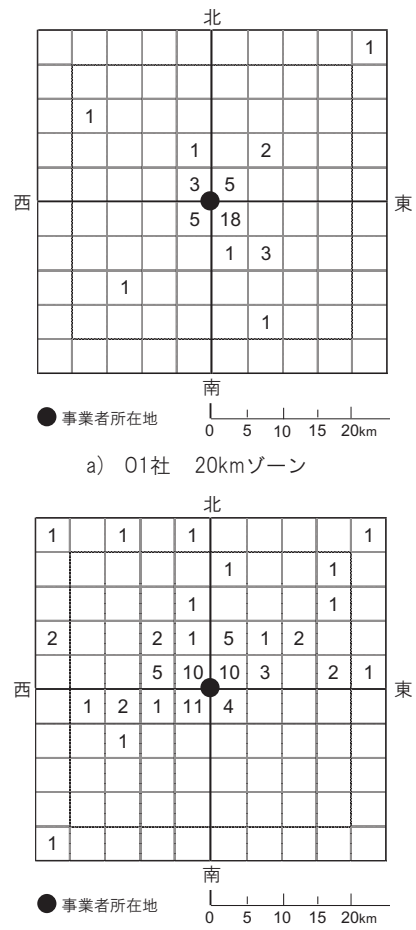

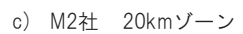

a) 01 社 $20 \mathrm{~km}$ ゾーン

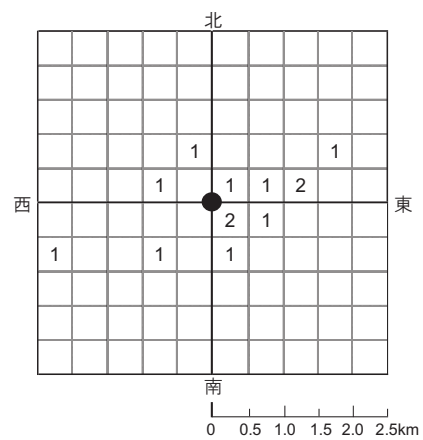

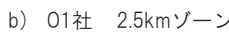

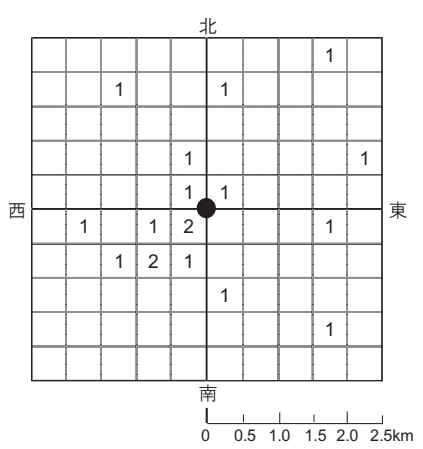

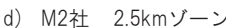

図 10 協力業者会メンバーの地域分布 
また、わが国では 1960 年代半ばより、アルミサッシやステンレス 流し台等に代表される住宅用部品が急速に普及した。それに伴い、 各部品メーカーが全国に販売店や指定工事店を組織し、部品製造か ら流通・販売網の整備、さらに施工に至るまでの垂直統合がなされ た。上下水道工事などのように地方自治体が指定する工事業者もあ る。これらの中には、一定の地域内に限って独占的に営業権を持ち、 工事を受注する者もあり、業態によっては専門工事業者を選択・決 定する工務店側の裁量が限定されることもある。

\section{（2）専門工事業者の調達}

前述のように、小規模住宅生産者は通常、協力業者会の限定され たメンバーに各種専門工事を発注する。そこで、ここでは、新たな 専門工事業者の採用・確保を、専門工事業者の調達として捉える。

図 9 によれば、小規模住宅生産者では、新たな専門工事業者を定 期的に採用するケース、または優れた専門工事業者を知った時に確 保するケースが多いことが分かる。それぞれ 3 割以上あり、合計す ると 7 割を超える。年間供給実績別に見ても大きな差異はないこと からも、これらが主な採用・確保の機会となっていると言える。な お、不足時に採用しているケースも少なくない。

専門工事業者においても、技能者の高齢化が進展しており、体力 的・技術的な低下等を理由に廃業する者もある。長期的な視点に立 てば、小規模住宅生産者にとって、後継者や若手の職人がいる将来 性の高い専門工事業者を新たに採用・確保する重要性は高い。ただ し、一般的に、創業以来維持している取引関係もあるように、可能 な限り長く継続される専門工事業者との取引関係は非常に限定的か つ固定的である ${ }^{10)}$ 。その上、既述のように協力業者会を形成し、 そのメンバーに工事発注する傾向が強い。

このような取引関係の中、 $\mathrm{A} 3$ 社や $\mathrm{D} 1$ 社等では、協力業者会メン バーの更新を要する時機に限り、同業他社や同一業種の専門工事業 者の紹介で知った、新規の専門工事業者へ試験的に発注する方法を 採っている。その際、新たに生じるリスクを適切に管理するため、
難易度の低い工事から順に発注する。つまり、試験的採用を通して、 専門工事業者の備える技術水準や人間的資質等を確認・評価し、採 用していることが分かる。

これらの傾向からすれば、小規模住宅生産者による新たな専門工 事業者の採用・確保は、協力業者会の質的な維持・向上と長期的視 点に立った協力業者会メンバーの更新にその主な動機があり、定期 的な採用といってもその頻度は決して高くないと言える。

次に、協力業者会を構成する専門工事業者は通常、社外組織であ ることから、それらの地域分布について、工務店と専門工事業者の 所在との関係から見る。図 10 は、それぞれの中央にあるの印を工務 店の所在地とし、グリッド内の数值は東西南北のグリッド内に拠点 を構える専門工事業者数を示している。

まず、地方都市近郊にある $\mathrm{O} 1$ 社では、事業拠点から $5 \mathrm{~km}$ グリッ ドの内側に全体の $73.8 \%$ （31/42 社）の専門工事業者があり、また $10 \mathrm{~km}$ グリッドの内側となると $90 \%$ （38/42 社）に達する。さらに、 $2.5 \mathrm{~km}$ グリッドの内側には 13 社 $(31.0 \%)$ が立地する。

同様に、都心部近郊にある M2 社について見る。ここでは、事業 拠点から $5 \mathrm{~km}$ グリッドの内側にあって、取引関係を持つ専門工事業 者は 35 社であり、全体 73 社のうち半数程度になる。10km グリッ ド以内では $72.6 \%$ （53/73 社）に達する。この数值は $\mathrm{O} 1$ 社に比べる と若干が低いが、 $2.5 \mathrm{~km}$ グリッドの内側に、協力業者会メンバーの うち 24.7\%（18/73 社）が立地している。

このことから、O 1 社、及び M2 社が地域の専門工事業者を中心と した取引関係を構築していることが分かる。

小規模住宅生産者は、専門工事業者に対して技術・技能水準だけ でなく、人間的な資質などを強く求めているが、前述のように、地 域の専門工事業者との取引関係を構築する特徵を持つ。すなわち、 地域の構成員であることを前提として、技術・技能水準と人間的な 資質といった小規模住宅生産者が求める条件を満たした専門工事業 者を中心に自社の協力業者会を形成していると言える。

表 8 資源統合プロセスにおける各種資源の用いられ方の概説

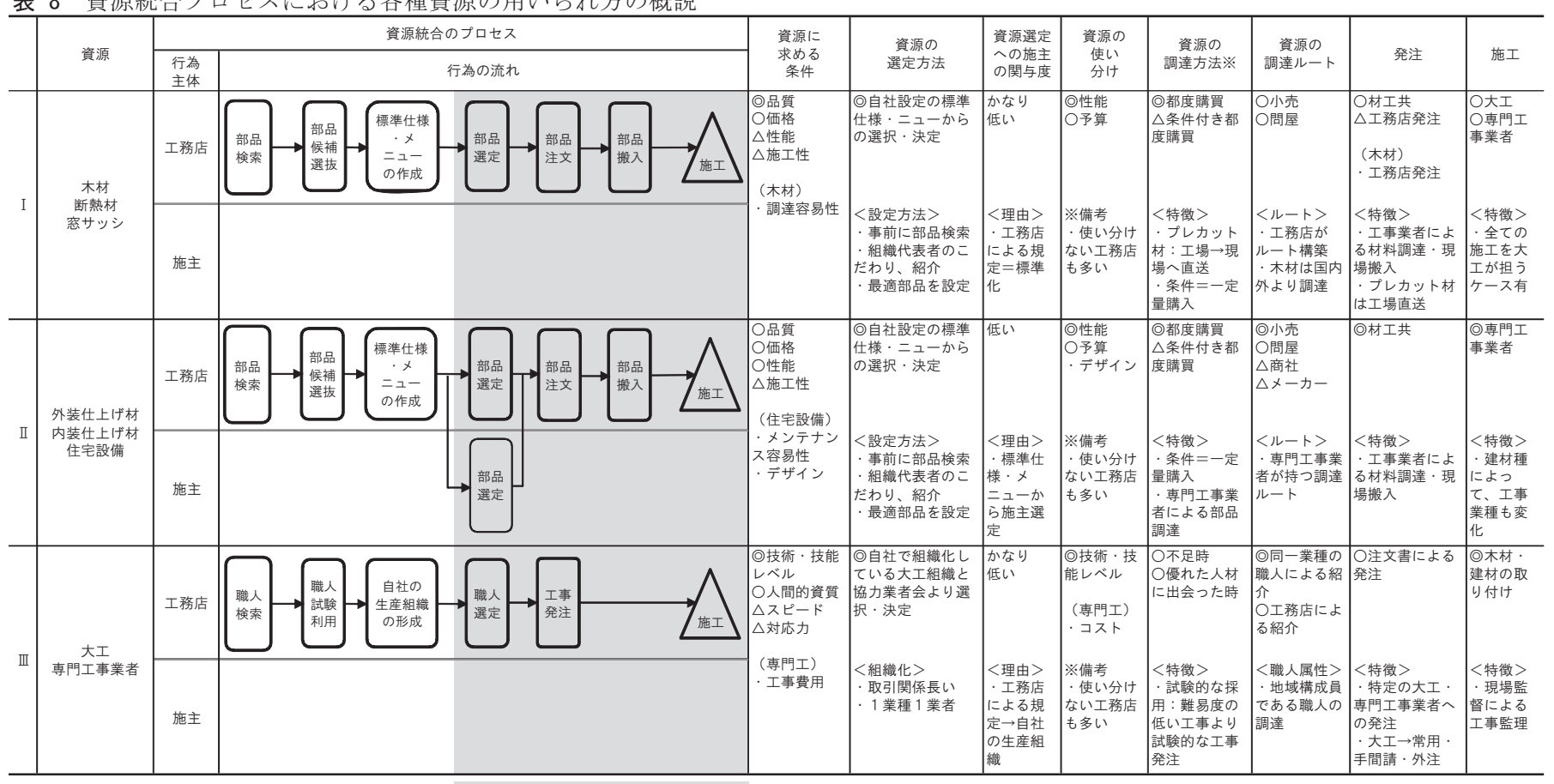




\section{5. まとめ}

本稿ではこれまでに、部品を木材と建材、並びに職人を大工と専 門工事業者に大きく資源を分類して、小規模住宅生産者による木造 注文住宅の新築工事におけるそれらの選定・調達のあり様について 明らかにした。以下に、その概要を整理する。なお、ここで得た分 析結果から、各種資源が用いられるプロセスとして 3 タイプ（部品： 2 タイプ、職人 : 1 タイプ）に分類し、表 8 にまとめた。

(1) 専門的知識の必要性や性能・品質の安定的な確保などのため、 部品は通常、工務店により自ら検索したものによって設定した 標準仕様やメニューの中から選定される。なお、仕上げ材や設 備については施主が選定に関わる傾向が若干強い。

（2）ストックヤードの保有率の低さやプレカット材の普及等によ り、自社で部品を備蓄する機能と機会が低下しており、木材を 含めて部品は通常、都度購買によって調達される。

（３）職人の組織化に加え、木造住宅の品質管理や施主との信頼関 係構築等を要因として、職人は工務店主導で大工組織や協力業 者会のメンバーより選定される。

（4）同業他社や関連工事業種の職人による紹介を通じて、主に地 域の職人が採用・確保されるが、特定の職人との間に長期的な 取引関係を構築しているため、新規採用・確保の頻度は低い。

これら（1）～（4）の整理から、小規模住宅生産者による木造 注文住宅の生産の仕組みを再考すると、そこに投入される部品及び 職人という資源の選定・調達は工務店の主導性が非常に強く働いて おり、今回の調查の範囲内では、限定された資源が用いられること が一般的であると結論付けられる。

最後に、上記の結果より、小規模住宅生産者による木造注文住宅 の生産活動の実態を、以下のように考察してまとめとする。

・個々の工務店は用いる資源を予め選択・決定する傾向が強く、そ れらの生産活動は、限られた事業エリア中で、仕様を固定した木 造注文住宅を供給している。

- 小規模住宅生産者の生産活動に多様性・個別性が存在する場合、 それはそれぞれの工務店が設定する限定的・画一的な生産活動に 生じる差異によるものである。

\section{注}

注 1) ここで言う前稿とは、日本建築学会計画系論文集第 639 号に揭載され た、角倉英明・松村秀一による「小規模住宅生産者による木造注文住 宅の生産システムに関する研究 その 1 事業形態から見た小規模住宅 生産者の特性」のことである。

注 2) 本研究では、小規模住宅生産者を、(1)主に木造注文住宅を供給し、そ の元請業者であること、(2)木造注文住宅の年間平均供給実績が 30 戸程 度以下であること、(3)八ウスメーカーなど他社からの独立性が高いこ と満たす事業者と定義した。

その上で、本研究では小規模住宅生産者の規模別傾向を捉えるため、 前稿と同様に木造注文住宅の年間平均供給実績が 3 戸以下の事業者を

$\lceil 3$ 戸以下の住宅生産者」、3 戸より多く 10 戸以下の事業者を「10 戸 以下の住宅生産者」そして 10 戸より多く 30 戸以下の事業者を「30戸 以下の住宅生産者」というように区分している。

注 3）（財）住宅保証機構の運営による住宅性能保証制度は、住宅登録を受け た住宅の品質・性能を保証する制度である。住宅供給業者及び住宅販 売業者等が当該制度を活用するためには業者登録の手続きを要する。 当該制度は、 2008 年 4 月「特定住宅瑕疵担保責任の履行の確保等に関 する法律」の施行に伴い、住宅瑕疪担保責任保険の運用が開始され、 2008 年 6 月末に住宅登録の受付を終了した。
注 4) 本研究における定義より、資源の選定行為は個別の新築工事に用いる 固有の資源の「選択」と「決定」の 2 つ大きく分けられる。なお、 インタビュー調查等を下にして、図 3、5、7 並びに 9 のように資源の 選択と決定における主体、及びその情報媒体を組み合わせ、各種資源 の選定方法を設定した。

木材の選定方法を例に見ると、「自社メニュー等から工務店が探して、 選択・決定」と比べて「務店が自社仕様によって指定」は、工務店 が選択と決定を主導する点では同様であるが、個別の新築工事におけ る資源選定の柔軟性は低い。また、「自社で用意したカタログ等の資料 から施主が選択・決定」と「自社メニューから施主が選択・決定」で は、施主が選択と決定の主体となっている点で共通しているが、工務 店が関与する度合いについては後者の方が強いという特徴がある。

注 5）本研究で行ったアンケート調查結果によれば、小規模住宅生産者のう ち約 7 割の事業者は自社の標準仕様を設定している。それらの多くは 組織代表者が自ら設定したものである。

注 6）本研究で行ったアンケート調査結果によれば、出身業種別の作業場・ 工場所有率は、総合工事業で $56.5 \%$ 、大工工事業で $63.6 \%$ 、建売・不動 産業で $34.5 \%$ である。また、ストックヤードの所有率はそれぞれ、 $47.1 \%$, $31.8 \% 、 34.5 \%$ である。

注 7）例えば、 $\mathrm{T} 3$ 社では、地産地消という観点からも、組織代表者が指定し た地場産の杉材を標準仕様としている。さらに、山林において実際に 住宅に使用寸る木材の伐採・切り出し・運搬・加工の過程を施主に見 学させ、顧客満足度を高名効果を狙う取り組みも行っている。

注 8）小規模住宅生産者における平均的な大工組織の規模は全体で 6 名、自 社大工はそのうち 4 割弱であり 2 名程度と試算できる。 また、建設業における雇用形態に基づいた技能者の処遇については、 蟹澤による既報 11 1) にて詳細に分析・整理されている。本稿では、こ れを参考にして、「専属的に利用可能な自社大工」を工務店が自社の正 社員として正規雇用している大工、及び自社で直接雇用して常時使用 している大工（契約上は請負であるが自社と常用的関係にある大工を 含む）と定義する。

注 9） A1 社、D1 社及び S1 社等では、将来増加が予想される改修工事に適切 に対応できる大工を育成するため、比較的容易な新築工事のうち年 1 〜 棟については、大工が自社の作業場で墨付け・手刻みによる木材 加工を行い、現場で組み立てる取り組みを実施している。

注 10）本研究で行ったインタビュー調查によれば、小規模住宅生産者では自 社の木造住宅についての専門工事業者の理解度を高めるため、協力業 者会向けの勉強会を毎月に 1 回程度実施している工務店は多い。

\section{参考文献}

1）遠藤和義：木造住宅生産社会論，東京大学修士論文，1985

2）角倉英明，松村秀一：小規模住宅生産者による木造注文住宅の生産システ ムに関する研究 その 1 事業形態から見た小規模住宅生産者の特性, 日本 建築学会計画系論文集, 第 639 号, pp. 1125-1131，2009.5

3）橘高義典，杉山央：新編 建築材料，市ヶ谷出版社，2003

4) 角倉英明: 小規模住宅生産者の存在形態に関する研究, 東京大学学位論文, 2007

5）財団法人日本住宅・木材技術センター: 木材需給と木材工業の現況（平成 19 年版), 2008

6）松村秀一：「住宅のできる世界」のしくみ，彰国社，1998

7）東樋口護：住宅の部品化に関する基礎的研究，京都大学学位論文，1985

8）財団法人住宅保証機構：平成 17 年度工務店経営実態調查報告書, 2008

9）総務省統計局：平成 17 年国勢調查（抽出詳細集計），2008

10）角倉英明，松村秀一：小規模な木造住宅生産者の集約機能に関寸る研究 一職人の集約機能について一, 日本建築学会大会学術講演梗概集（関東）, F-1，pp. 1183-1184, 2006

11）蟹澤宏剛：専門工事業の従業者に関する考察，日本建築学会計画系論文 集，第 583 号，pp.113-120，2004.9

（2010年 5 月18日原稿受理，2010年10月 7 日採用決定） 